Review

\title{
Therapeutic Features and Updated Clinical Trials of Mesenchymal Stem Cell (MSC)-Derived Exosomes
}

\author{
Byung-Chul Lee ${ }^{1}$, Insung Kang ${ }^{2}$ and Kyung-Rok Yu ${ }^{3, * * 1}$ \\ 1 Translational Stem Cell Biology Branch, National Heart, Lung, and Blood Institute, NIH, Bethesda, \\ MD 20892, USA; byung-chul.lee@nih.gov \\ 2 Program in Developmental Endocrinology and Genetics, Eunice Kennedy Shriver National Institute of Child \\ Health and Human Development, NIH, Bethesda, MD 20892, USA; insung.kang@nih.gov \\ 3 Department of Agricultural Biotechnology and Research Institute of Agriculture and Life Sciences, \\ Seoul National University, Seoul 08826, Korea \\ * Correspondence: cellyu@snu.ac.kr
}

Citation: Lee, B.-C.; Kang, I.; Yu, K.-R. Therapeutic Features and Updated Clinical Trials of Mesenchymal Stem Cell (MSC)-Derived Exosomes. J. Clin. Med. 2021, 10, 711. https://doi.org/ $10.3390 / \mathrm{jcm} 10040711$

Academic Editor:

Katharina Schallmoser

Received: 29 January 2021

Accepted: 4 February 2021

Published: 11 February 2021

Publisher's Note: MDPI stays neutral with regard to jurisdictional claims in published maps and institutional affiliations.

Copyright: (c) 2021 by the authors. Licensee MDPI, Basel, Switzerland. This article is an open access article distributed under the terms and conditions of the Creative Commons Attribution (CC BY) license (https:// creativecommons.org/licenses/by/ $4.0 /)$.

\begin{abstract}
Identification of the immunomodulatory and regenerative properties of mesenchymal stem cells (MSCs) have made them an attractive alternative therapeutic option for diseases with no effective treatment options. Numerous clinical trials have followed; however, issues such as infusional toxicity and cellular rejection have been reported. To address these problems associated with cellbased therapy, MSC exosome therapy was developed and has shown promising clinical outcomes. MSC exosomes are nanosized vesicles secreted from MSCs and represent a non-cellular therapeutic agent. MSC exosomes retain therapeutic features of the cells from which they originated including genetic material, lipids, and proteins. Similar to MSCs, exosomes can induce cell differentiation, immunoregulation, angiogenesis, and tumor suppression. MSC exosomes have therefore been employed in several experimental models and clinical studies. Here, we review the therapeutic potential of MSC-derived exosomes and summarize currently ongoing clinical trials according to disease type. In addition, we propose several functional enhancement strategies for the effective clinical application of MSC exosome therapy.
\end{abstract}

Keywords: exosome therapy; clinical trials; immunomodulation; regeneration; angiogenesis

\section{Background}

Mesenchymal stem cells (MSCs) have unique biomedical properties due to their stemness: they can simulate their own proliferation and can differentiate into multi-lineage cells [1]. MSCs have low immunogenicity due to low expression of major histocompatibility complex (MHC) class I molecules and expression of only a few MHC class II molecules [2,3]. Importantly, MSCs have been demonstrated to have immunomodulatory and regenerative functions in a variety of disease models [4-8]. Given these properties, MSCs have been evaluated in clinical trials over several decades [9]. Even though the results of some preclinical studies and clinical trials using MSCs were promising, clinical outcomes often did not improve significantly or disease severity increased after MSC therapy in other studies, making MSC-based therapy controversial [10]. These discrepancies in the effects of MSCs could be due to poor engraftment of infused MSCs [11,12], donor-dependent variation, or possible infusional toxicity due to lodging of cells in the microvasculature $[13,14]$. Moreover, senescence of MSCs during in vitro expansion makes the cells less productive, and can increase disease severity by causing inflammaging, which refers to a persistent, low-grade, systemic pro-inflammatory status that is characteristic of the normal aging process of mammalian tissues and cells [15].

To guarantee consistent and stable therapeutic effects, improved MSC therapeutic strategies are needed [16]. Strategies should take into account current hurdles such as low in vivo survival, inaccurate delivery to inflamed lesions, and donor-to-donor variation. 
Researchers have attempted to enhance the therapeutic efficacy of MSCs by improving their migration into lesions $[17,18]$ and by preconditioning them with bioactive molecules such as IFN- $\gamma$ and TNF- $\alpha[19,20]$. Furthermore, use of co-administration strategies including scaffolds and hydrogels have enabled more deliberate and accurate disease treatment. An alternative approach to improve MSC-based therapy is to use membrane-bound extracellular vesicles (EVs) or exosomes [21].

From prokaryotes to eukaryotes, released EVs are involved in intercellular communication by transmitting biological signals between cells. Based on their biogenesis, EVs are categorized into three main classes: exosomes, microvesicles, and apoptotic bodies [22]. With the smallest size range of around 50 to $150 \mathrm{~nm}$, exosomes are released into the extracellular environment when multivesicular bodies fuse with the cell membrane. These nanometer-sized vesicles contain many constituents of cells, including cytokines and growth factors, signaling lipids, and mRNA and regulatory miRNAs, with variation in the components of the exosome according to their cellular origin. Notably, MSC exosomes may be more suitable for clinical application than MSCs. MSC exosomes are likely to be free of immunogenic problems and unlikely to be trapped in the lung or liver like infused MSCs, while still maintaining the therapeutic functions of their cells of origin. Given the proven therapeutic potential of MSC-derived exosomes in preclinical studies, there are currently 16 ongoing clinical studies investigating the therapeutic application of MSC-derived exosomes in various diseases [23].

In the present study, we provide a comprehensive review of the therapeutic potential of exosomes from various MSC sources and their clinical applications based on the 16 clinical trials registered in a public database by discussing their effects in a disease-specific manner.

\section{Therapeutic Properties of MSC Exosomes}

Mesenchymal stem cells have been evaluated as alternative therapies for a variety of rare diseases due to their ability to immunomodulate activated immune cells and stimulate tissue regeneration. Two main cellular behaviors underlie their therapeutic effects: direct cell-mediated action and environmental changes induced by release of soluble factors [24]. The MSC secretome, which refers to soluble factors released into the culture medium, has recently attracted attention. Among the released substances, microvesicles (MVs, $0.1-1 \mathrm{~mm}$ in diameter) and exosomes (50-150 $\mathrm{nm}$ in diameter) function as intercellular mediators between MSCs and target cells, which include MSCs [25]. Nanosized exosomes (Figure 1) in particular are considered MSC substitutes because they have similar therapeutic features to MSCs. Exosomes may have greater potential for clinical application than MSCs because of their low immunogenic and tumorigenic potential [26]. Thus, the use of MSC exosomes has opened up new avenues for clinical application of MSCs.

The most important property of MSC-derived exosomes is their 'cargo' function; they contain a variety of validated therapeutic agents. Contents of MSC exosomes include nucleic acids, proteins, and lipids, with more than 850 gene products and 150 miRNAs described [27]. Moreover, their composition can vary depending on the source the MSCs were isolated from and the external stimuli, which is one of the reasons why MSCs from different sources exhibit different characteristics or therapeutic effects [26]. Although the characteristics of exosomes from different MSC sources can vary, they are in general therapeutic. MSC exosomes horizontally transfer their contents such as mRNAs, miRNAs, and proteins into target cells to modify the cellular functions of these cells [28]. Although the mechanisms of MSC exosome endocytosis have not yet been fully elucidated, several cellular processes including vesicle-cell fusion, phagocytosis, micropinocytosis, and/or receptor-mediated endocytosis are assumed to be involved in internalization [29]. However, some researchers have claimed that internalization of MSC exosome into target cells is not necessary for them to exert a therapeutic effect $[30,31]$. 


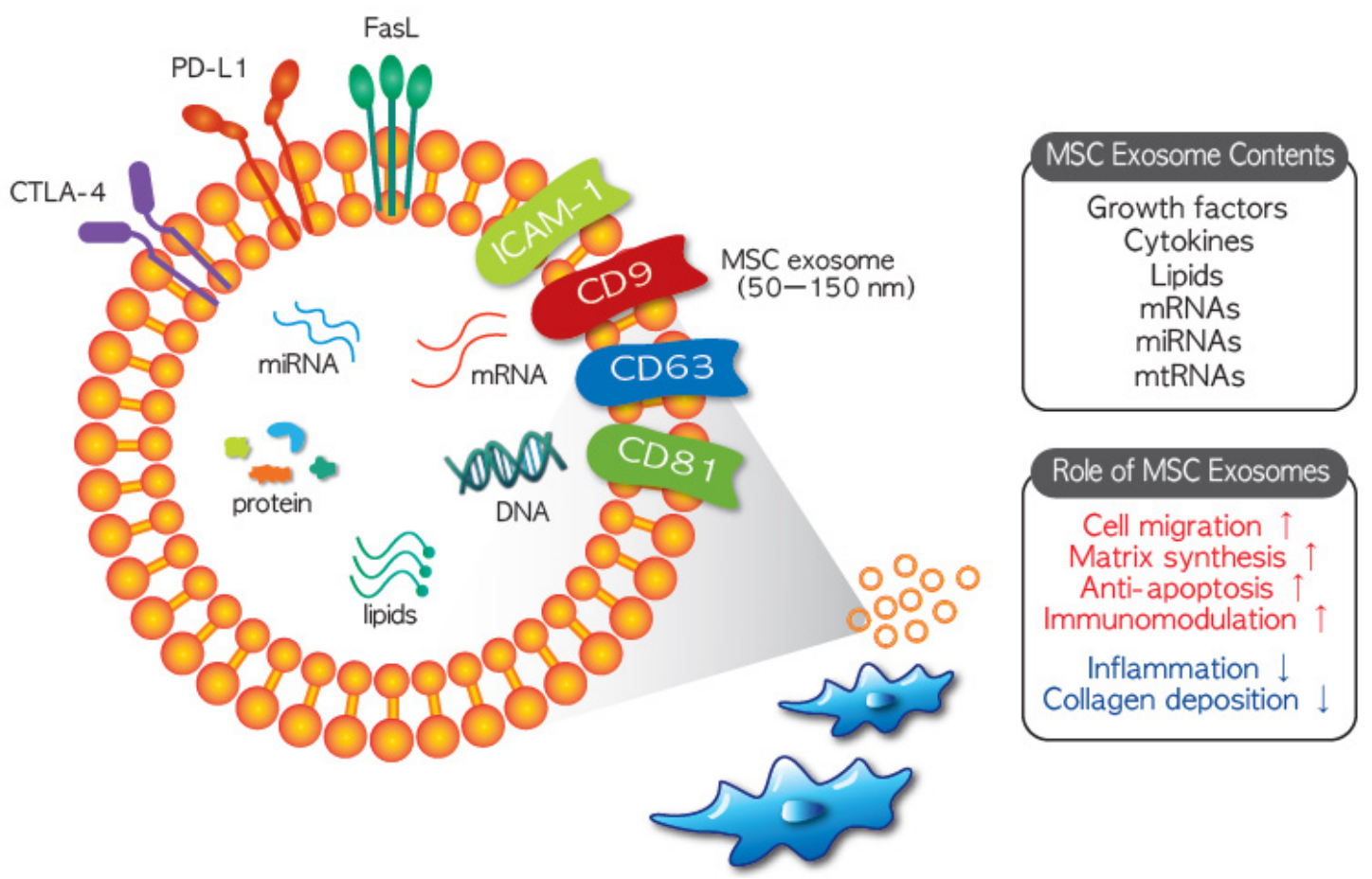

Figure 1. Composition and therapeutic function of MSC (mesenchymal stem cells) exosomes. Exosomes derived from MSCs may contain growth factors, cytokines, DNA, lipids, mRNAs, miRNAs, and mtRNAs. Similar as their cells from which they originated, MSC exosomes possess therapeutic properties including stimulation of cell migration and extracellular matrix synthesis, anti-apoptotic effects, immunomodulation and anti-inflammatory effects, and stimulation of collagen deposition. Due to these distinctive therapeutic features, the feasibility of MSC exosome therapy is currently being assessed in several clinical studies.

Several clinical features of MSC exosomes have been described in preclinical studies. For example, MSC exosomes accelerate the tissue regeneration process by regulating proliferation and apoptosis of endogenous cells [32-34]. MSC exosomes also affect the fate decision of some immune cells, thus facilitating attenuation of excessive inflammation or a return to immune homeostasis [35-37]. Furthermore, MSC exosomes induce angiogenesis by stimulating various cellular signaling pathways [38-40]. Given these promising results, safety and efficacy of application of MSC exosomes are currently being evaluated in clinical trials targeting various diseases. Below, we review the therapeutic potential of MSC exosomes according to disease type.

\section{Immune-Related Diseases}

The most important clinical feature of MSCs and MSC-derived exosomes is their immunomodulatory function [41]. Immune-related diseases are generally due to imbalances in the immune system and subsequent responses of the body against biased activation of specific types of immune responses. MSC exosomes have attracted interest as major mediators of MSC-mediated immunomodulation of various types of immune cells. Exosomes derived from MSCs play a role in regulating various immune cell subsets and subsequently facilitating immune homeostasis, like their cells of origin. MSC exosomes have been shown to have suppressive functions against activated immune cells including effector $\mathrm{T}$ cells, microglial cells [42], macrophages [43], and NK cells [44]. In contrast, MSC exosomes facilitate lineage determination toward regulatory type immune cells such as tolerogenic dendritic cells [37], M2 macrophages [45], and regulatory T cells [42], promoting immune system homeostasis. The modulatory functions proven in preclinical studies have inspired clinical trials targeting various autoimmune diseases.

MSC exosomes efficiently suppress excessive proliferation and activation of Th1 cells. For example, CD39-expressing CD4 ${ }^{+}$Th1 cells initiated adenosine-related apoptosis after 
internalizing BM-MSC derived exosomes in an animal graft-versus-host disease (GvHD) model [46]. Furthermore, the therapeutic function against GvHD has demonstrated in human study [47]. According to a previous study using a contact hypersensitivity (CHS) model mouse, infusion with exosomes from umbilical cord-derived MSCs (UC-MSCs) resulted in a decreased level of Th1 cells and subsequent secretion of IFN- $\gamma$ with increased Treg induction. Internalization of EVs was also shown to be associated with decreased expression of signal transducer and activator of transcription 1 (STAT1), which has a crucial role in Th1 cell development [48]. Although simultaneous increases in Th17 and Treg by treatment with MSC exosomes have been reported [49], Th17 cells and Tregs are generally considered to be in a competitive relationship. Indeed, MSC exosomes have been reported to promote Tregs while suppressing the polarization of $\mathrm{T}_{\mathrm{H}} 17$ cells by SphK1mediated SP1 enrichment in an aplastic anemia (AA) model [50] and increase miR-125a and miR-125b expression in an experimental colitis model [51]. MSC exosomes also suppress excessive allergic inflammation. Cho et al. reported that infusion of exosomes derived from adipose tissue-derived MSCs (AT-MSCs) alleviated atopic dermatitis (AD) by improving pathological symptoms and infiltration of mast cells into skin lesions [52]. Asthma, a major allergic disease of the airways, was controlled by MSC EV's infusion due to suppression of group 2 innate lymphoid cell (ILC2) pathways [53] or promotion of the Treg population [54]. Given these preclinical findings, the clinical potential of MSC exosomes is currently being assessed in four different immune disorders (Table 1)

Approximately $35-50 \%$ of patients suffer from GvHD after allogeneic hematopoietic stem cell (HSC) transplantation, which is caused by donated hematopoietic stem cells perceiving recipient body systems as foreign and attacking them. Chronic GvHD (cGvHD) is characterized by rashes, abdominal swelling, dry eyes, vision changes, shortness of breath, muscle weakness, and tightness in joints [55,56]. Among these symptoms, dry eye is the most frequent, occurring in $40-76 \%$ of patients, and its severity could reflect disease prognosis. Keratoconjunctivitis sicca is caused by lymphocytic infiltration around lacrimal glands, resulting in tissue degeneration and malfunction [57]. Since immunosuppressants such as corticosteroids or cyclosporine A nonspecifically suppress the immune system and are not appropriate in all patients, MSCs have been considered as an alternative therapy to treat dry eye in cGvHD [58]. A clinical trial evaluating the therapeutic efficacy of umbilical MSC (UMSC) exosomes at alleviating dry eye symptom was registered in December 2019 (NCT04213248). Notably, the aims of this trial are to analyze the responses of disease indicators, such as the amount of tears and the degree of damage to tissues, to exosome treatment with the exosomes applied in the form of eye drops rather than intravascular injection.

Type 1 diabetes mellitus (T1DM) is another well-known autoimmune disease that needs life-long management. Symptoms include weight loss, exhaustion, itchy skin, and blurry eyesight. Immune cells in the body attack pancreatic $\beta$ cells for unknown reasons, adversely affecting insulin production and subsequent glucose metabolism. As there is as yet no specific treatment, patients with T1DM require daily insulin injections or installation of an insulin pump to maintain a normal range of blood glucose levels $[59,60]$. To address the absence of drugs specific for treating T1DM, MSC exosomes have been explored. Nojehdehi et al. reported that exosomes derived from AD-MSCs had a therapeutic effect in a streptozotocin-induced T1DM mouse model by increasing the Treg population in the spleen and regenerating pancreatic islets [61]. The exosome from menstrual MSCs has shown similar therapeutic potential in a rat model, potentially mediated by a pancreatic and duodenal homeobox 1 pathway [62]. A clinical trial evaluating the effects of repetitive intravenous infusions of UCB blood-derived MSC exosomes in T1DM is currently underway (NCT02138331). 
Table 1. Ongoing clinical trials using MSC exosomes [23].

\begin{tabular}{|c|c|c|c|c|c|c|}
\hline No. & Study Title & Conditions & Interventions & Locations & Last Update & Ref. \\
\hline 1 & $\begin{array}{l}\text { Effect of UMSCs Derived Exosomes on } \\
\text { Dry Eye in Patients With cGVHD }\end{array}$ & Dry Eye & UMSC exosomes & $\begin{array}{l}\text { Zhongshan Ophthalmic Center, } \\
\text { Guangzhou, Guangdong, China }\end{array}$ & 21 February 2020 & NCT04213248 \\
\hline 2 & $\begin{array}{c}\text { Effect of Microvesicles and Exosomes } \\
\text { Therapy on } \beta \text {-cell Mass in Type I } \\
\text { Diabetes Mellitus (T1DM) }\end{array}$ & Diabetes Mellitus Type 1 & MSC exosomes & $\begin{array}{l}\text { Sahel Teaching Hospital, Sahel, } \\
\text { Cairo, Egypt }\end{array}$ & 14 May 2014 & NCT02138331 \\
\hline \multirow[t]{2}{*}{3} & \multirow{2}{*}{$\begin{array}{l}\text { Evaluation of Adipose Derived Stem } \\
\text { Cells Exo.in Treatment of Periodontitis }\end{array}$} & \multirow[t]{2}{*}{ Periodontitis } & \multirow[t]{2}{*}{ AD-MSC exosomes } & $\begin{array}{l}\text { Beni-Suef University, Ban̄̄ } \\
\text { Suwayf, Egypt }\end{array}$ & \multirow[t]{2}{*}{17 February 2020} & \multirow[t]{2}{*}{ NCT04270006 } \\
\hline & & & & Cairo University, Cairo, Egypt & & \\
\hline 4 & $\begin{array}{l}\text { Exosome of Mesenchymal Stem Cells } \\
\text { for Multiple Organ Dysfuntion } \\
\text { Syndrome After Surgical repair of } \\
\text { Acute Type A aortic Dissection }\end{array}$ & Multiple Organ Failure & MSC exosomes & $\begin{array}{l}\text { Fujian Medical University, } \\
\text { Fujian, China }\end{array}$ & 6 May 2020 & NCT04356300 \\
\hline 5 & MSC-Exos Promote Healing of MHs & Macular Holes & MSC-Exo & $\begin{array}{l}\text { Tianjin Medical University } \\
\text { Hospital, Tianjin, China }\end{array}$ & 17 September 2019 & NCT03437759 \\
\hline 6 & $\begin{array}{l}\text { MSC EVs in Dystrophic } \\
\text { Epidermolysis Bullosa }\end{array}$ & $\begin{array}{c}\text { Dystrophic } \\
\text { Epidermolysis Bullosa }\end{array}$ & AGLE 102 & $\begin{array}{l}\text { Aegle therapetics, Miami, } \\
\text { Florida, USA }\end{array}$ & 12 January 2021 & NCT04173650 \\
\hline 7 & $\begin{array}{l}\text { The Use of Exosomes In } \\
\text { Craniofacial Neuralgia }\end{array}$ & Neuralgia & Exosomes & $\begin{array}{c}\text { Neurological Associates of } \\
\text { West LA, } \\
\text { Santa Monica, California, USA }\end{array}$ & 6 January 2020 & NCT04202783 \\
\hline \multirow{3}{*}{8} & \multirow{3}{*}{$\begin{array}{c}\text { Focused Ultrasound and Exosomes to } \\
\text { Treat Depression, Anxiety, } \\
\text { and Dementias }\end{array}$} & Refractory Depression & \multirow{3}{*}{ Exosomes } & \multirow{3}{*}{$\begin{array}{l}\text { Neurological Associates of } \\
\text { West LA, } \\
\text { Santa Monica, California, USA }\end{array}$} & \multirow{3}{*}{6 January 2020} & \multirow{3}{*}{ NCT0420277C } \\
\hline & & Anxiety Disorders & & & & \\
\hline & & Neurodegenerative Diseases & & & & \\
\hline 9 & $\begin{array}{l}\text { The Safety and the Efficacy Evaluation } \\
\text { of Allogenic Adipose MSC-Exos in } \\
\text { Patients With Alzheimer's Disease }\end{array}$ & Alzheimer Disease & $\begin{array}{l}\text { MSCs-Exos } \\
\text { administrated for nasal } \\
\text { drip Dosage }\end{array}$ & $\begin{array}{l}\text { Ruijin Hospital Shanghai Jiao } \\
\text { Tong University School of } \\
\text { Medicine, Shanghai, China }\end{array}$ & 29 September 2020 & NCT04388982 \\
\hline
\end{tabular}


Table 1. Cont.

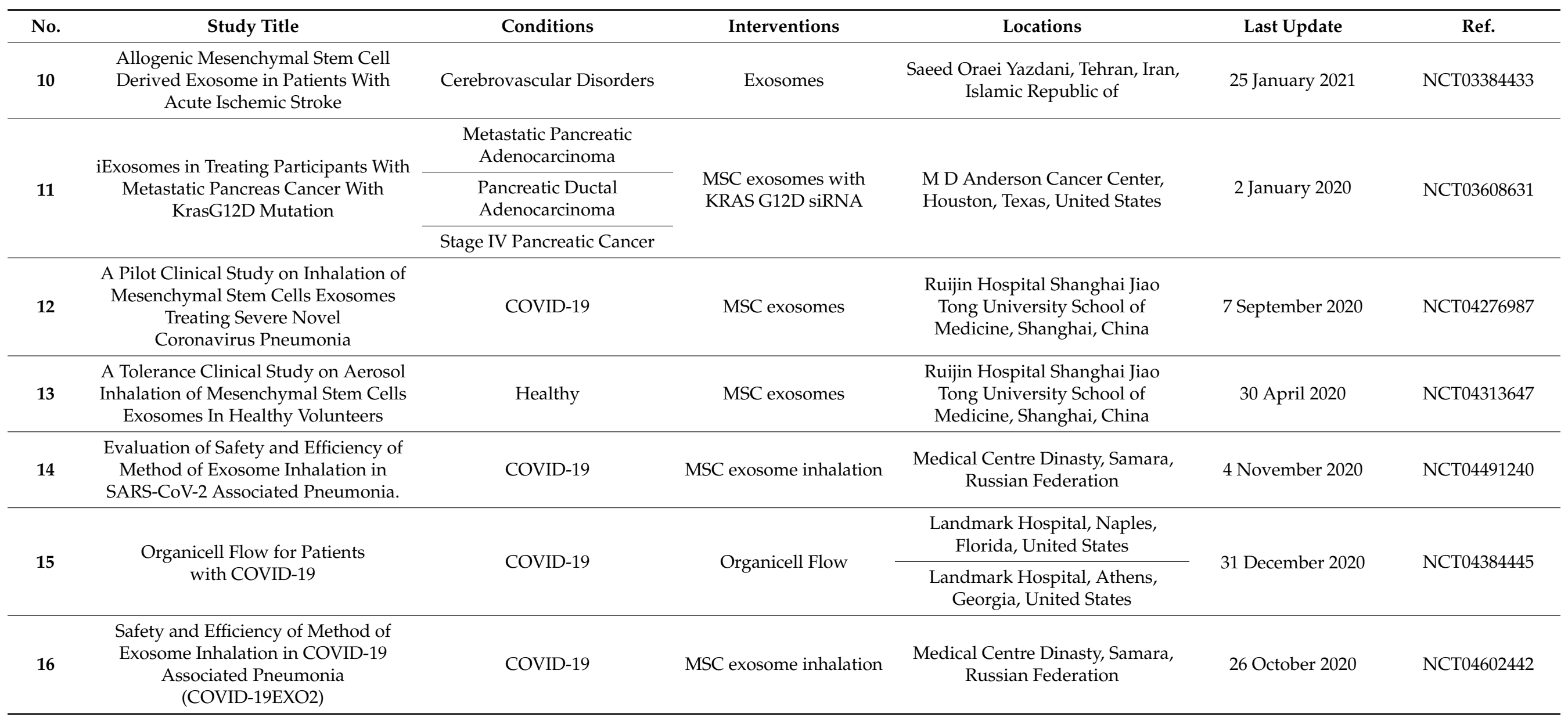


In addition to these autoimmune diseases, MSC exosomes have been shown to alleviate experimental periodontitis. Dysbiosis in the periodontal cavity promotes the growth of pathogenic microbiota such as Porphyromonas gingivalis and Fusobacterium nucleatum, contributing to autoantibody generation and subversion of host immune responses after invasion of these autoantibodies into the circulatory system and various organs [63]. Xu et al. demonstrated that exosomes from $\mathrm{P} 2 \times 7$ receptor $(\mathrm{P} 2 \times 7 \mathrm{R})$ gene-modified periodontal ligament stem cells (PDLSCs) restored the compromised regenerative function of neighboring cells by binding to the GREM-1 protein and upregulating the expression of miRNAs including miR-3679-5p, miR-6515-5p, and miR-6747-5p [64]. Exosomal microRNA-155-5p from PDLSCs directly rectified the imbalance in the Th17/Treg ratio by regulating the expression of sirtuin-1 (SIRT1) in a chronic periodontitis experimental model [65]. Moreover, adipose tissue-derived MSC (AD-MSC) exosomes have been reported to play a supportive role in periodontal ligament and tissue regeneration [66]. In a clinical study, the therapeutic efficacy of autologous administration of AD-MSC exosomes at alleviating gingival inflammation and tissue damage in patients aged between 18 to 50 years is being evaluated (NCT04270006). Lastly, multiple organ dysfunction syndrome (MODS), a death-causing postoperative complication after cardiovascular surgery [67], is being treated with exosomes isolated from UC-MSCs (NCT04356300). The proinflammatory cytokine, IL-6, is often employed as a prognostic indicator of MODS, because IL-6 is released in response to tissue injury and inflammatory stimuli [68,69]. To assess the safety and efficacy of MSC exosomes, short- and long-term immune responses, concentration of IL-6 (early 3 days), and allergic reactions including rashes, itching, and anaphylactic shock (up to 6 months) as well as organ failure assessment scores are being investigated.

\section{Wound Healing}

Exosomes from various MSCs have been shown to accelerate wound repair [70-73]. Even though wound healing is a complicated physiological phenomenon, MSC exosomes contribute to the recovery process by promoting proliferation, differentiation, positioning of cellular constituents of skin [74], and inducing the differentiation of immune cells [45]. Subcutaneous administration of exosomes derived from iPSC-MSCs has been shown to accelerate wound repair in an animal model by promoting type I and III collagen and elastin secretion by fibroblasts [71]. In addition, transplanted MSC exosomes play a crucial role in not only angiogenesis but maturation of vessels in wound sites to boost the healing process $[71,72]$.

Epidermolysis bullosa (EB) is a disease characterized by skin fragility and blistering in response to mechanical trauma with 30 distinct subtypes [75]. Among disease subtypes, recessive dystrophic epidermolysis bullosa (RDEB) resulting from mutations in the type VII collagen (COL7A1) gene and subsequent lack of protein production can be alleviated by bone marrow-derived MSC (BM-MSC) EVs because they donate their own type VII collagen and induce host fibroblasts to produce this protein [76]. Given these promising results, a phase I/IIA clinical study was launched to test the safety and feasibility of a topical application of allogeneic MSC exosomes in EB. Dose-limiting toxicity and wound size recession will be assessed in 10 participants (NCT04173650). Moreover, another prospective clinical study using BM-MSCs has reported that intravenous infusion was well tolerated with no severe complications up to 12 months and that there was transient alleviation of EB symptoms for 2 months (NCT02323789). In this study, the authors emphasized the relevance of the secretome, including EVs and exosome, in tissue regeneration [77].

Besides skin and epidermal wounds, MSC exosomes have been also applied to wound healing of other organs. Idiopathic macular hole $(\mathrm{MH})$ can induce retinal detachment in highly myopic eyes [78]. Although surgical management via pars plana vitrectomy (PPV) is used to treat this condition in the majority of the patients, those patients with particularly large and long-lasting MHs have a poor prognosis after standard PPV surgery [79]. Alternative or auxiliary tools to promote functional and physical recovery from MHs have therefore been explored. Zhang et al. reported that six of seven patients (two patients 
treated with MSC exosomes and five patients treated with umbilical cord-derived MSC exosomes by intravitreal injection after surgical procedures) showed complete macular closure while five patients showed improved visual function as assessed by best corrected visual acuity (BCVA) [79], the primary outcome measure of the clinical study (NCT03437759).

\section{Neurological Diseases}

The focus in stem cell therapy has shifted from direct cell-to-cell interactions to paracrine interactions after acknowledging that transplanted cells migrate poorly to existing neural networks and that their therapeutic effect is orchestrated by secretion of heterogeneous EVs [80]. Moreover, advances in modifying molecules to enable them to cross the blood-brain barrier (BBB) has brought exosomes in the spotlight as therapeutic candidates for neurological diseases and mental disorders. Alvarex-Erviti et al. developed neuron-targeting exosomes loaded with GAPDH siRNA [81]. Injection of these exosomes intravenously resulted in specific gene knockdown in neuronal cells [81]. Given the evidence that exosomes can cross the BBB, Xin et al. administered rat bone marrow-derived MSC exosomes containing miR-17-92 to a stroke model via an intravenous route and demonstrated enhancement of oligodendrogenesis, neurogenesis, and neuroplasticity with functional recovery [82]. Recently, intravenously administrated MSC exosomes have been modified to target specific regions of the brain. Cui et al. modified exosomes with the central nervous system-specific rabies viral glycoprotein (RVG) peptide to target them to the cortex and hippocampus in an Alzheimer's disease mouse model. RVG-tagged MSC exosomes reduced plaque accumulation and astrocyte activation and decreased expression of the pro-inflammatory mediators TNF- $\alpha$, IL- $\beta$, and IL- 6 and increased levels of the anti-inflammatory factors IL-10, IL-4, and IL-13 [83].

Another direct pathway to the brain is the nasal cavity; this route can be used to bypass the BBB to deliver therapeutic agents to the brain [84]. In a pilocarpine-induced status epilepticus mice model, MSC-derived exosomes were administrated intranasally and were reported to reach the hippocampus within $6 \mathrm{~h}$, where they had neuroprotective and anti-inflammatory effects [85]. Perets et al. evaluated the effects of MSC-exosome intranasal administration in BTBR $\mathrm{T}+\mathrm{tf} / \mathrm{J}$ (BTBR) mice, an accepted model of autistic-like behavior, and reported increased male-male social interaction with reduced repetitive behavior and improvement in maternal behavior, suggesting a therapeutic strategy to reduce symptoms associated with autism spectrum disorders [86]. Guo et al. were able to detect MSC exosomes in spinal cord lesions of a spinal cord injury model after intranasal delivery. Specifically, phosphatase and tensin homolog small interfering RNA (ExoPTEN)loaded exosomes reduced the expression of PTEN, thereby improving structural and electrophysiological function in spinal cord injury.

Given that exosomes delivered intravenously can cross the BBB, the Jordan group from Neurological Associates of West Los Angeles has initiated two separate trials targeting craniofacial neuralgia (NCT04202783) and neurodegenerative disease-driven depression, anxiety, and dementia (NCT04202770). The Wang group from Ruijin Hospital in China has initiated a phase I/II clinical trial to explore the safety and efficacy of exosomes derived from allogeneic adipose tissue derived-MSCs for the treatment of mild to moderate dementia due to Alzheimer's disease (NCT04388982). They plan to administer exosomes at three different doses twice a week for 12 weeks and will explore the safety and efficiency of these exosomes and provide a clinical dose reference for subsequent trials.

\section{Cardiovascular Diseases}

Although mortality rates have declined dramatically over the past two decades, cardiovascular and circulatory diseases are still recognized as the leading causes of death worldwide [87]. While the primary cause of death in the United States is cardiovascular disease [88], ischemic heart disease, a major cause of cardiovascular disease, leads the death rate in China [89]. Due to cardiomyocyte loss in ischemic heart diseases, investigators have focused on the importance of regenerative medicine to prevent cardiovascular disease. The 
ability of MSCs to differentiate into a variety of cell types has led to investigation of MSCs as major cell-based therapeutic agents for cardiac tissue regeneration and repair.

Although MSC stem cell therapy results have been promising, it is still unclear how they work. Freyman et al. observed only 30,000 cells from $50 \times 10^{6}$ engrafted cells injected intravenously, representing $0.06 \%$ of the population, in the infarct zones of swine heart after acute myocardial infarction [90]. Timmers et al. showed that MSC-conditioned media treatment after myocardial infarction in swine preserved cardiac function, suggesting that MSC secretions may have angiogenic potential [91]. Shao et al. compared MSC-derived exosome-treated and stem cell-treated rat myocardial infarction models and reported that MSC exosomes inhibited cardiac fibrosis and inflammation and improved cardiac function to a greater extent than MSCs [92].

Given that the function of secretory exosomes is determined by the materials they contain such as cytokines, proteins, mRNAs, miRNAs, and rRNAs, studies have been performed to identify key factors involved in cardiac regeneration. Anderson et al. identified 1927 proteins in MSC-derived exosomes and analyzed nuclear factor-kappaB; signaling as a key mediator of MSC-induced angiogenesis [38]. In rat myocardial infarction model, Wang et al. showed that the cardioprotective effect of MSC exosomes was mediated by miR-21 enhanced cell survival via the PTEN/Akt pathway [93]. A recent study reported that MSC exosomes containing miR-25-3p had cardioprotective effects by decreasing EZH2, H2K27me3, and SOCS3 expression, alleviating myocardial infarction by targeting pro-apoptotic proteins and inflammatory genes [94]. According to the finding that MSCderived exosomes promote angiogenesis remodeling and functional recovery after stroke, a recent clinical study form Isfahan University of Medical Sciences is exploring the use of miR-124-loaded MSC-derived exosomes to improve angiogenesis in patients with acute stroke (NCT03384433).

\section{Cancers}

The application of MSC-derived exosomes in cancer therapy has been investigated for several years. Although there are some controversies on the functions on tumor progression, several reports showed the inhibition effect of MSC EVs in tumor metastasis. Patients in recession or those who are undergoing chemotherapy occasionally experience cancer recurrence due to undetectable and slow-growing dormant cells. In 2014, Ono et al. reported that the BM-MSC exosome can inhibit metastatic cancer cell proliferation and consequently promote dormancy in metastatic breast cancer cells through miR23b-mediated suppression of MARCKS [95]. Moreover, cancer cell priming was found to be essential for the anticancer effect of the MSC exosome by promoting cycling quiescence in cancer cells [96,97]. MSC exosomes can also mediate changes in drug resistance development by gastric cancer cells via calcium/calmodulin-dependent protein kinase (CaM-K) and Raf/MEK/ERK kinase cascade signaling, which would improve the efficiency of chemotherapy [98]. In contrast to their effects in cardiovascular disease, MSC-derived exosomes function as intercellular mediators between tumor cells and suppress angiogenesis by directly transferring anti-angiogenic molecules such as miR-16 and suppressing VEGF expression [99].

However, Lin et al. revealed that MSC exosomes accelerate migration of cancer cells and expression of cancer-related pathways, including the Wnt signaling pathway [100]. Similarly, MSC exosomes were shown to induce the epithelial-mesenchymal transition (EMT) in gastric cancer cells and enhance tumorigenicity by upregulating cancer growth and migration [101]. Their angiogenic properties are also of concern in the context of promoting cancer growth. Thus, MSC exosome-cancer therapy is sometimes referred to as a "double-edged sword" [102,103]. To overcome this, researchers have focused on the cargo function of MSC exosomes. For example, exosomes derived from MSCs treated with taxol (paclitaxel; PTX) showed improved tumor-suppressive effects, resulting in direct tumor cell growth inhibition at a 1000-fold decreased concentration compared to taxol mono-treatment $[104,105]$. Moreover, siRNA targeting tumor-related genes such as 
polo-like kinase-1 (PLK-1) can be loaded within MSC-derived exosomes for intravesical therapy [106].

Accordingly, MSC exosomes containing siRNA targeting oncogenic Kras ${ }^{\mathrm{G} 12 \mathrm{D}}$ mutations are being employed against pancreatic cancer in a clinical trial (NCT03608631). The Kras ${ }^{\mathrm{G} 12 \mathrm{D}}$ mutation, which is a common mutation in pancreatic cancer, is a promising therapeutic target. Kalluri group has developed engineered exosomes (iExosomes) expressing CD47 and si- or sh-RNA for Kras ${ }^{\mathrm{G} 12 \mathrm{D}}$. They demonstrated that iExosomes suppressed oncogenic Kras and enhanced the survival of pancreatic cancer mouse model $[107,108]$. Based on these findings, the safety and feasibility of iExosomes need to be evaluated in patients with Kras ${ }^{\mathrm{G} 12 \mathrm{D}}$-related pancreatic cancer in clinical trials.

\section{MSC Exosomes as a COVID-19 Supportive Treatment}

Recently, coronavirus disease 2019 (COVID-19), caused by rapid and widespread infection by the novel coronavirus severe acute respiratory syndrome coronavirus 2 (SARSCoV-2), has become the biggest general threat to both global public health and the world economy. Accordingly, pragmatic methods to prevent and treat infection are greatly in demand [109-114].

Similar to other coronaviruses such as severe acute respiratory syndrome (SARS$\mathrm{CoV}$ ) and Middle East respiratory syndrome (MERS-CoV), SARS-CoV-2 primarily targets the human respiratory system and symptoms include fever, dry cough, sputum, fatigue, headache, and dyspnea. Importantly, this virus affects the lower respiratory tract resulting in infiltration of the upper lobes of the lungs and subsequent hypoxemia, unlike other coronaviruses. In addition, patients infected by SARS-CoV-2 occasionally present with diarrhea as one of the symptoms [115]. SARS-CoV-2 binds to the angiotensin-converting enzyme 2 (ACE2) receptor present on host lung cells using its $S$ protein and once internalized, begins to replicate itself [116]. Although $\mathrm{CD} 4^{+}$and $\mathrm{CD} 8^{+} \mathrm{T}$ cells expressing HLA-DR and CD38, respectively, remain activated, the number of these cells in the peripheral blood of patients with COVID-19 is reportedly reduced [117]. SARS-CoV-2 infection disrupts the function of a patient's immune system. Dysregulated immune effector cells secrete large amounts of pro-inflammatory cytokines (e.g., IFN- $\alpha$, IFN- $\gamma$, IL-1 $\beta$, IL-6, IL-12, IL-18, IL-33, TNF- $\alpha$, TGF $\beta$ ) and chemokines (e.g., CCL2, CCL3, CCL5, CXCL8, CXCL9, CXCL10), leading to a so-called "cytokine storm" [118]. Increased cytokine secretion and subsequent infiltration of the lung tissue by activated immune cells such as inflammatory monocytes and neutrophils triggers acute respiratory distress syndrome (ARDS), which is widely recognized as one of the most critical factors resulting in death from COVID-19 [119]. Thus, an effective treatment to prevent a COVID-19-induced cytokine storm is urgently needed.

As we described above, the most prominent feature of MSCs or exosomes derived from MSCs is their immunomodulation ability. MSC exosomes or EVs have already been employed to treat airway diseases such as asthma [54], bronchopulmonary dysplasia [43,120], and ARDS [121]. MSCs and their derivatives have also been shown to efficiently suppress influenza virus infection by mitigating symptoms and restoring normal physiological function. In addition, clinical trials have demonstrated that MSC transplantation reduces the severity of influenza virus-induced lung injuries and lowers mortality, suggesting a potential role for MSCs and MSC EVs in COVID-19 treatment [122-124]. Even though the production of exosomes is technically and economically inefficient compared to MSCs themselves, exosomes have advantages for treating airway-borne diseases because exosomes are not trapped in the lungs unlike MSCs injected via the intravenous route. Moreover, with a size of around $100 \mathrm{~nm}$, exosomes can be applied via aerosol inhalation while preserving their immunomodulatory function [125]. Due to their unique phospholipid membrane structure, bioactive molecules, including promising drugs, can be inserted into exosomes and their effects could be maximized by fusing target cell membranes and transferring the cargo into the cytoplasm [126].

Currently, there are four clinical trials exploring the use of MSC exosomes as a supportive treatment for COVID-19-infected patients. The first case entitled 'A Pilot Clinical Study 
on Inhalation of Mesenchymal Stem Cells Exosomes Treating Severe Novel Coronavirus Pneumonia' was designed to explore the therapeutic potential of aerosol inhalation of exosomes derived from allogenic AT-MSCs in patients with severe disease (NCT04276987). The safety of this MSC exosome treatment is being assessed in a separate clinical study (NCT04313647). Another study led by Russian clinicians is testing whether inhalation of MSC-derived exosomes can suppress over-response of the immune system to the virus and stimulate regenerative processes (NCT04491240, NCT04602442). Lastly, even though an intravenous route will be employed for actual injection, administration of EVs derived from BM-MSCs or 'ExoFlo' is being evaluated as a treatment for moderate-to-severe ARDS in patients with COVID-19 (NCT04493242) [127]. In addition to these three studies, studies using EVs or exosomes from non-MSC sources including donor-originated COVID-19 specific T-cells (NCT04389385) or amniotic stem and epithelial cells with over 300 growth factors, cytokines, and chemokines derived from human amniotic fluid (HAF) (NCT04384445) are also being performed (Table 1). Even if these ongoing studies report successful outcomes, there are still several issues that need to be resolved. Of note, safety issues should be addressed before actual clinical application, because MSC EVs reportedly have procoagulant activity as do their cells of origin [128]. A cohort study revealed that severe COVID-19 patients present with hypercoagulability as one of their symptoms [129]; thus, procoagulant factors as well as excessive proinflammatory cytokines in the exosome cargo must be removed prior to infusion as recommended in plasma exchange therapy [130]. Moreover, to expedite and consolidate preclinical processes, well-established disease models such as a nonhuman primate models are needed to assess the safety and efficacy of novel therapeutics and potential vaccines.

\section{Future Perspectives and Concluding Remarks}

In the present study, we comprehensively reviewed the therapeutic features and current status of clinical trials of MSC exosomes according to disease type (Figure 2). Although preclinical studies have reported promising results, several enhancements of MSC exosome therapy are required to obtain superior outcomes. First, the suitability of MSCs for application to specific diseases should be evaluated prior to exosome isolation. Genetic modification of MSCs can improve the therapeutic function of exosomes derived from these MSCs. One of the primary targets of genetic modification could be miRNAs. For example, exosomes derived from MSCs overexpressing miR-92a-3p facilitated superior chondrogenesis and cartilage protection compared to naïve cells [131] and the bone regenerative function of AD-MSC exosomes was shown to be enhanced by miR-375 overexpression [132]. Moreover, overexpression of miR-143 improved the suppressive function of MSC exosomes on cancer cell migration and invasion [133]. There are numerous other miRNAs that are potential targets for genetic manipulation in exosomes in addition to the miRNAs discussed above. Overexpression of proteins with specific therapeutic roles such as CXCR4 [134] and GATA-4 [135] has also been demonstrated to improve the function of MSC exosomes. Thus, prior to genetic manipulation of MSCs, it is important to identify precise genetic targets that can be manipulated in exosomes to treat specific diseases.

Second, the therapeutic effect of MSC exosomes is reinforced by direct delivery of target molecules into MSC exosomes. A variety of insertion methods including passive loading, sonication, electroporation, extrusion, and light-induced loading have already been developed [136]. As we discussed above, anticancer drugs have been loaded into exosomes to achieve better clinical outcomes [104,105]. Sun et al. previously reported that the anti-inflammatory activity of curcumin, a potent immune suppressant, was improved by encapsulating it in exosomes [137]. Another anti-inflammatory drug, namely the STAT3 inhibitor JSI124, efficiently suppressed neuroinflammation when introduced in the form of exosomes via the intranasal route [138]. In addition to exosome-mediated drug delivery, loading and delivery of long endogenous RNAs or small interfering RNAs has been shown to inhibit cancers and results in apoptosis of leukemic cells [139,140]. 


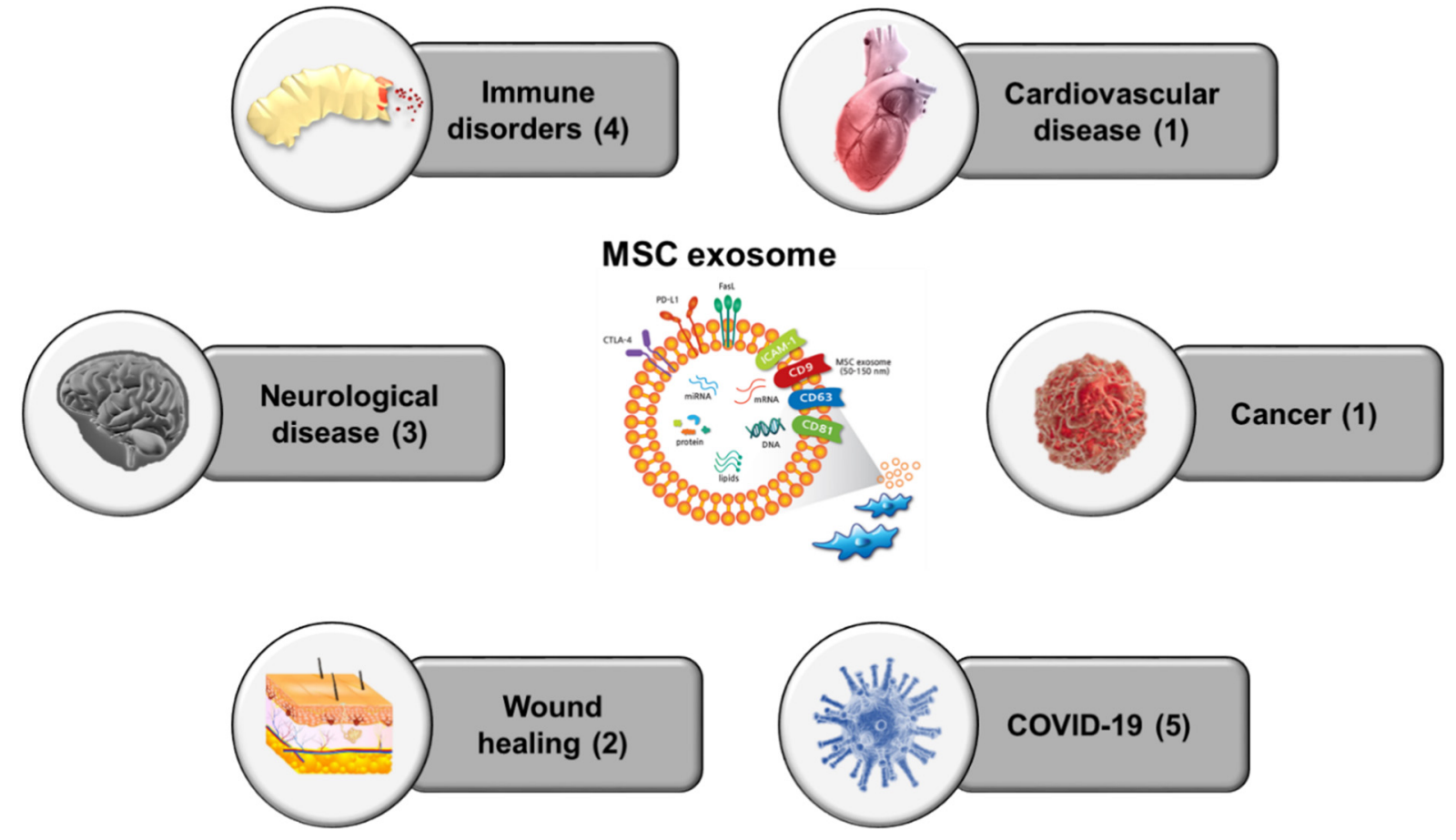

Figure 2. Current clinical trials of MSC exosome therapy. Summarized figure of 16 registered clinical trials categorizing by disease type. The numbers in the parentheses indicated ongoing clinical studies ( Jan 2021).

Supportive materials can be utilized to maximize the therapeutic functions of MSC exosomes. Among biocompatible aids, various hydrogels have recently attracted attention. Placenta-derived MSC exosomes containing chitosan hydrogel showed enhanced therapeutic effectiveness with retention in vivo and stability of exosome contents, including proteins and miRNAs, in an ischemic experimental model [141]. Other hydrogels have been shown to strengthen the wound repair process by complementing physical defects $[73,142]$. In a similar context, packing of tissues with MSC exosomes and scaffolds resulted in better outcomes than naïve treatment in bone or endometrium regeneration models [143-145]. Additionally, pretreatment of MSCs with bacterial substances such as lipopolysaccharide can be used to develop disease- or type-specific exosomes suitable for the resolution of chronic inflammation [146]. Lastly, surface modification of pullulan, which can bind to hepatocyte receptors, was shown to enhance the therapeutic effects of MSC exosomes by improving their targeting of injured organs [147].

For exosome-based therapy to be safe and successful for clinical applications, the biodistribution of the administered exosomes must be explored. Currently, there are various studies to evaluate the biodistribution of exosomes obtained from different sources and treated in different disease models. In mice with acute kidney injury, intravenously delivered MSC exosomes were detected from the site of injury after $5 \mathrm{~h}$ and were not

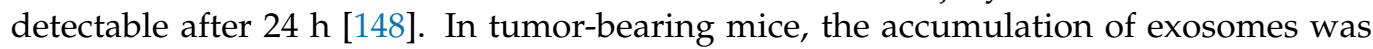
significantly higher in the tumor area at 24 and $48 \mathrm{~h}$ following intraperitoneal injection [108]. In general, intravenously delivered exosomes are known to accumulate mainly in the liver and spleen, however, according to the cell source and route of administration, the biodistribution pattern can be different [149]. When designing a therapeutic strategy using exosomes, careful consideration for MSC source, administration route, and biodistribution must be preceded.

In conclusion, successful MSC exosome therapy of various rare diseases requires disease- and/or patient-customized therapy. To do so, detailed identification of the characteristics and pathogenesis of each target disease, selection of feasible exosome cargo, determination of methods to regulate selected factors, and improved delivery to lesions are required. 
Author Contributions: B.-C.L. and I.K. conceptualized and wrote the original draft. K.-R.Y. conceptualized, reviewed and edited the manuscript. All authors have read and agreed to the published version of the manuscript.

Funding: This work was supported by the New Faculty Startup Fund from Seoul National University and a grant from the Basic Research Program (2019R1C1C1008896) through the National Research Foundation of Korea (NRF) funded by the Korean government.

Institutional Review Board Statement: Not applicable.

Informed Consent Statement: Not applicable.

Data Availability Statement: Not applicable.

Conflicts of Interest: The authors declare no conflict of interest.

\section{References}

1. Da Silva Meirelles, L.; Chagastelles, P.C.; Nardi, N.B. Mesenchymal stem cells reside in virtually all post-natal organs and tissues. J. Cell Sci. 2006, 119, 2204-2213. [CrossRef]

2. Lee, M.; Jeong, S.Y.; Ha, J.; Kim, M.; Jin, H.J.; Kwon, S.-J.; Chang, J.W.; Choi, S.J.; Oh, W.; Yang, Y.S.; et al. Low immunogenicity of allogeneic human umbilical cord blood-derived mesenchymal stem cells in vitro and in vivo. Biochem. Biophys. Res. Commun. 2014, 446, 983-989. [CrossRef] [PubMed]

3. Hass, R.; Kasper, C.; Böhm, S.; Jacobs, R. Different populations and sources of human mesenchymal stem cells (MSC): A com-parison of adult and neonatal tissue-derived MSC. Cell Commun. Signal. 2011, 9, 1-14. [CrossRef]

4. Corcione, A.; Benvenuto, F.; Ferretti, E.; Giunti, D.; Cappiello, V.; Cazzanti, F.; Risso, M.; Gualandi, F.; Mancardi, G.L.; Pistoia, V.; et al. Human mesenchymal stem cells modulate B-cell functions. Blood 2006, 107, 367-372. [CrossRef] [PubMed]

5. Le Blanc, K.; Davies, L.C. Mesenchymal stromal cells and the innate immune response. Immunol. Lett. 2015, 168, 140-146. [CrossRef]

6. Zappia, E.; Casazza, S.; Pedemonte, E.; Benvenuto, F.; Bonanni, I.; Gerdoni, E.; Giunti, D.; Ceravolo, A.; Cazzanti, F.; Frassoni, F.; et al. Mesenchymal stem cells ameliorate experimental autoimmune encephalomyelitis inducing T-cell anergy. Blood 2005, 106, 1755-1761. [CrossRef] [PubMed]

7. Wang, D.; Zhang, H.; Liang, J.; Li, X.; Feng, X.; Wang, H.; Hua, B.; Liu, B.; Lu, L.; Gilkeson, G.S.; et al. Allogeneic mesenchymal stem cell transplantation in severe and refractory systemic lupus erythematosus: 4 years of experience. Cell Transplant. 2013, 22, 2267-2277. [CrossRef] [PubMed]

8. Forbes, G.M.; Sturm, M.J.; Leong, R.W.; Sparrow, M.P.; Segarajasingam, D.; Cummins, A.G.; Phillips, M.; Herrmann, R.P. A phase 2 study of allogeneic mesenchymal stromal cells for luminal Crohn's disease refractory to biologic therapy. Clin. Gastroenterol. Hepatol. 2014, 12, 64-71. [CrossRef]

9. Kabat, M.; Bobkov, I.; Kumar, S.; Grumet, M. Trends in mesenchymal stem cell clinical trials 2004-2018: Is efficacy optimal in a narrow dose range? Stem Cells Transl. Med. 2020, 9, 17-27. [CrossRef] [PubMed]

10. Raval, Z.; Losordo, D.W. Cell therapy of peripheral arterial disease. Circ. Res. 2013, 112, 1288-1302. [CrossRef]

11. Li, L.; Chen, X.; Wang, W.E.; Zeng, C. How to Improve the survival of transplanted mesenchymal stem cell in ischemic heart? Stem Cells Int. 2015, 2016, 1-14. [CrossRef]

12. Karp, J.M.; Teo, G.S.L. Mesenchymal stem cell homing: The devil is in the details. Cell Stem Cell 2009, 4, 206-216. [CrossRef]

13. Siegel, G.; Kluba, T.; Hermanutz-Klein, U.; Bieback, K.; Northoff, H.; Schäfer, R. Phenotype, donor age and gender affect function of human bone marrow-derived mesenchymal stromal cells. BMC Med. 2013, 11, 146. [CrossRef] [PubMed]

14. Kang, I.; Lee, B.C.; Choim, S.W.; Lee, J.Y.; Kim, J.J.; Kim, B.E.; Kim, D.H.; Lee, S.E.; Shin, N.; Seo, Y.; et al. Donor-dependent variation of human umbilical cord blood mesenchymal stem cells in response to hypoxic preconditioning and amelioration of limb ischemia. Exp. Mol. Med. 2018, 50, 35. [CrossRef] [PubMed]

15. Lee, B.C.; Yu, K.R. Impact of mesenchymal stem cell senescence on inflammaging. BMB Rep. 2020, 53, 65-73. [CrossRef] [PubMed]

16. Fehrer, C.; Lepperdinger, G. Mesenchymal stem cell aging. Exp. Gerontol. 2005, 40, 926-930. [CrossRef]

17. Duijvestein, M.; Wildenberg, M.E.; Welling, M.M.; Hennink, S.; Molendijk, I.; van Zuylen, V.L.; Bosse, T.; Vos, A.C.W.; de Jonge-Muller, E.S.M.; Roelofs, H.; et al. Pretreatment with interfer-on- $\gamma$ enhances the therapeutic activity of mesenchymal stromal cells in animal models of colitis. Stem Cells 2011, 29, 1549-1558. [CrossRef]

18. Fan, H.; Zhao, G.; Liu, L.; Liu, F.; Gong, W.; Liu, X.; Yang, L.; Wang, J.; Hou, Y. Pre-treatment with IL-1 $\beta$ enhances the efficacy of MSC transplantation in DSS-induced colitis. Cell. Mol. Immunol. 2012, 9, 473-481. [CrossRef] [PubMed]

19. François, M.; Romieu-Mourez, R.; Li, M.; Galipeau, J. Human MSC Suppression correlates with cytokine induction of indoleamine 2,3-Dioxygenase and bystander M2 macrophage differentiation. Mol. Ther. 2012, 20, 187-195. [CrossRef]

20. Szabó, E.; Fajka-Boja, R.; Kriston-Pál, É.; Hornung, Á.; Makra, I.; Kudlik, G.; Uher, F.; Katona, R.L.; Monostori, É.; Ágnes, C. Licensing by inflammatory Cytokines abolishes heterogeneity of immunosuppressive function of mesenchymal stem cell population. Stem Cells Dev. 2015, 24, 2171-2180. [CrossRef] [PubMed] 
21. Zavatti, M.; Beretti, F.; Casciaro, F.; Bertucci, E.; Maraldi, T. Comparison of the therapeutic effect of amniotic fluid stem cells and their exosomes on monoiodoacetate-induced animal model of osteoarthritis. Biofactors 2020, 46, 106-117. [CrossRef]

22. El Andaloussi, S.; Mäger, I.; Breakefield, X.O.; Wood, M.J.A. Extracellular vesicles: Biology and emerging therapeutic opportunities. Nat. Rev. Drug Discov. 2013, 12, 347-357. [CrossRef]

23. U.S. National Library of Medicine. ClinicalTrials.gov Database. Available online: http:/ /www.clinicaltrials.gov/ (accessed on 27 January 2021).

24. Yagi, H.; Soto-Gutierrez, A.; Parekkadan, B.; Kitagawa, Y.; Tompkins, R.G.; Kobayashi, N.; Yarmush, M.L. Mesenchymal stem Cells: Mechanisms of immunomodulation and homing. Cell Transplant. 2010, 19, 667-679. [CrossRef] [PubMed]

25. Yeo, R.W.Y.; Lai, R.C.; Zhang, B.; Tan, S.S.; Yin, Y.; Teh, B.J.; Lim, S.K. Mesenchymal stem cell: An efficient mass producer of exosomes for drug delivery. Adv. Drug Deliv. Rev. 2013, 65, 336-341. [CrossRef] [PubMed]

26. Mendt, M.; Rezvani, K.; Shpall, E. Mesenchymal stem cell-derived exosomes for clinical use. Bone Marrow Transplant. 2019, 54, 789-792. [CrossRef]

27. Toh, W.; Lai, R.C.; Hui, J.H.P.; Lim, S.K. MSC exosome as a cell-free MSC therapy for cartilage regeneration: Implications for osteoarthritis treatment. Semin. Cell Dev. Biol. 2017, 67, 56-64. [CrossRef] [PubMed]

28. Phinney, D.G.; Pittenger, M.F. Concise review: MSC-Derived exosomes for Cell-Free Therapy. Stem Cells 2017, 35, 851-858. [CrossRef]

29. McKelvey, K.J.; Powell, K.L.; Ashton, A.W.; Morris, J.M.; McCracken, S.A. Exosomes: Mechanisms of uptake. J. Circ. Biomark. 2015, 4, 7. [CrossRef] [PubMed]

30. Li, X.; Wang, S.; Zhu, R.; Li, H.; Han, Q.; Zhao, R.C. Lung tumor exosomes induce a pro-inflammatory phenotype in mesenchymal stem cells via NFkB-TLR signaling pathway. J. Hematol. Oncol. 2016, 9, 1-12. [CrossRef]

31. Xunian, Z.; Kalluri, R. Biology and therapeutic potential of mesenchymal stem cell-derived exosomes. Cancer Sci. 2020, 111, 3100-3110. [CrossRef]

32. Zhang, S.; Chuah, S.J.; Lai, R.C.; Hui, J.H.P.; Lim, S.K.; Toh, W. MSC exosomes mediate cartilage repair by enhancing proliferation, attenuating apoptosis and modulating immune reactivity. Biomaterials 2018, 156, 16-27. [CrossRef]

33. Nakamura, Y.; Miyaki, S.; Ishitobi, H.; Matsuyama, S.; Nakasa, T.; Kamei, N.; Akimoto, T.; Higashi, Y.; Ochi, M. Mesenchymalstem-cell-derived exosomes accel-erate skeletal muscle regeneration. FEBS Lett. 2015, 589, 257-265. [CrossRef] [PubMed]

34. Zhang, S.; Chu, W.; Lai, R.C.; Lim, S.K.; Hui, J.H.P.; Toh, W. Exosomes derived from human embryonic mesenchymal stem cells promote osteochondral regeneration. Osteoarthr. Cartil. 2016, 24, 2135-2140. [CrossRef] [PubMed]

35. Zhao, J.; Li, X.; Hu, J.; Chen, F.; Qiao, S.; Sun, X.; Gao, L.; Xie, J.; Xu, B. Mesenchymal stromal cell-derived exosomes attenuate myocardial ischaemia-reperfusion injury through miR-182-regulated macrophage polarization. Cardiovasc. Res. 2019, 115, 1205-1226. [CrossRef] [PubMed]

36. Zhang, B.; Yeo, R.W.Y.; Lai, R.C.; Sim, E.W.K.; Chin, K.C.; Lim, S.K. Mesenchymal stromal cell exosome-enhanced regulatory T-cell production through an antigen-presenting cell-mediated pathway. Cytotherapy 2018, 20, 687-696. [CrossRef] [PubMed]

37. Shahir, M.; Hashemi, S.M.; Asadirad, A.; Varhram, M.; Kazempour-Dizaji, M.; Folkerts, G.; Garssen, J.; Adcock, I.M.; Mortaz, E. Effect of mesenchymal stem cell-derived exosomes on the induction of mouse tolerogenic dendritic cells. J. Cell. Physiol. 2020, 235, 7043-7055. [CrossRef]

38. Anderson, J.D.; Johansson, H.J.; Graham, C.S.; Vesterlund, M.; Pham, M.T.; Bramlett, C.S.; Montgomery, E.N.; Mellema, M.S.; Bardini, R.L.; Contreras, Z.; et al. Comprehensive proteomic analysis of mesenchymal stem cell exosomes reveals modulation of angiogenesis via nuclear factor-kappaB signaling. Stem Cells 2016, 34, 601-613. [CrossRef]

39. Teng, X.; Chen, L.; Chen, W.; Yang, J.; Yang, Z.; Shen, Z. Mesenchymal Stem cell-derived exosomes improve the microenvironment of infarcted myocardium contributing to angiogenesis and anti-inflammation. Cell. Physiol. Biochem. 2015, 37, 2415-2424. [CrossRef]

40. Gonzalez-King, H.; García, N.A.; Ontoria-Oviedo, I.; Ciria, M.; Montero, J.A.; Sepúlveda, P. Hypoxia inducible factor-1 $\alpha$ potentiates jagged 1-Mediated angiogenesis by mesenchymal stem cell-derived exosomes. Stem Cells 2017, 35, 1747-1759. [CrossRef]

41. Kang, J.Y.; Oh, M.-K.; Joo, H.; Park, H.S.; Chae, D.-H.; Kim, J.; Lee, H.-R.; Oh, I.-H.; Yu, K.-R. Xeno-free condition enhances therapeutic functions of human wharton's jelly-derived mesenchymal stem cells against experimental colitis by upregulated indoleamine 2,3-dioxygenase activity. J. Clin. Med. 2020, 9, 2913. [CrossRef]

42. Riazifar, M.; Mohammadi, M.R.; Pone, E.J.; Yeri, A.; Lässer, C.; Segaliny, A.I.; McIntyre, L.L.; Shelke, G.V.; Hutchins, E.; Hamamoto, A.; et al. Stem cell-derived exosomes as nanotherapeutics for autoimmune and neurodegenerative disorders. ACS Nano 2019, 13, 6670-6688. [CrossRef] [PubMed]

43. Willis, G.R.; Fernandez-Gonzalez, A.; Anastas, J.; Vitali, S.H.; Liu, X.; Ericsson, M.; Kwong, A.; Mitsialis, S.A.; Kourembanas, S. Mesenchymal Stromal cell exosomes ameliorate experimental bronchopulmonary dysplasia and restore lung function through macrophage immunomodulation. Am. J. Respir. Crit. Care Med. 2018, 197, 104-116. [CrossRef]

44. Sotiropoulou, P.A.; Perez, S.A.; Gritzapis, A.D.; Baxevanis, C.N.; Papamichail, M. Interactions between human mesenchymal stem cells and natural killer cells. Stem Cells 2006, 24, 74-85. [CrossRef] [PubMed]

45. He, X.; Dong, Z.; Cao, Y.; Wang, H.; Liu, S.; Liao, L.; Jin, Y.; Yuan, L.; Li, B. MSC-derived exosome promotes M2 polarization and enhances cutaneous wound healing. Stem Cells Int. 2019, 2019, 1-16. [CrossRef] [PubMed] 
46. Amarnath, S.; Foley, J.E.; Farthing, D.E.; Gress, R.E.; Laurence, A.; Eckhaus, M.A.; Métais, J.Y.; Rose, J.J.; Hakim, F.T.; Felizardo, T.C.; et al. Bone marrow-derived mesenchymal stromal cells harness purinergenic signaling to tolerize human T h1 cells in vivo. Stem Cells 2015, 33, 1200-1212. [CrossRef] [PubMed]

47. Kordelas, L.; Rebmann, V.; Ludwig, A.-K.; Radtke, S.; Ruesing, J.; Doeppner, T.R.; Epple, M.; Horn, P.A.; Beelen, D.W.; Giebel, B. MSC-derived exosomes: A novel tool to treat therapy-refractory graft-versus-host disease. Leukemia 2014, 28, 970-973. [CrossRef]

48. Guo, L.; Lai, P.; Wang, Y.; Huang, T.; Chen, X.; Luo, C.; Geng, S.; Huang, X.; Wu, S.; Ling, W.; et al. Extracellular vesicles from mesenchymal stem cells prevent contact hypersensitivity through the suppression of Tc1 and Th1 cells and expansion of regulatory T cells. Int. Immunopharmacol. 2019, 74, 105663. [CrossRef]

49. Bolandi, Z.; Mokhberian, N.; Eftekhary, M.; Sharifi, K.; Soudi, S.; Ghanbarian, H.; Hashemi, S.M. Adipose derived mesenchymal stem cell exosomes loaded with miR-10a promote the differentiation of Th17 and Treg from naive CD4+ T cell. Life Sci. 2020, 259, 118218. [CrossRef]

50. Li, Y.; Wang, F.; Guo, R.; Zhang, Y.; Chen, D.; Li, X.; Tian, W.; Xie, X.; Jiang, Z. Exosomal sphingosine 1-phosphate secreted by mesenchymal stem cells regulated Treg/Th17 balance in aplastic anemia. IUBMB Life 2019, 71, 1284-1292. [CrossRef]

51. Yang, R.; Huang, H.; Cui, S.; Zhou, Y.; Zhang, T.; Zhou, Y. IFN- $\gamma$ promoted exosomes from mesenchymal stem cells to attenuate colitis via miR-125a and miR-125b. Cell Death Dis. 2020, 11, 1-12. [CrossRef]

52. Cho, B.S.; Kim, J.O.; Ha, D.H.; Yi, Y.W. Exosomes derived from human adipose tissue-derived mesenchymal stem cells alleviate atopic dermatitis. Stem Cell Res. Ther. 2018, 9, 1-5. [CrossRef] [PubMed]

53. Fang, S.B.; Zhang, H.Y.; Wang, C.; He, B.X.; Liu, X.Q.; Meng, X.C.; Peng, Y.Q.; Xu, Z.B.; Fan, X.L.; Wu, Z.J.; et al. Small extracellular vesicles derived from human mesenchymal stromal cells prevent group 2 innate lymphoid cell-dominant allergic airway inflammation through delivery of miR-146a-5p. J. Extracell. Vesicles 2020, 9, 1723260. [CrossRef] [PubMed]

54. Du, Y.M.; Zhuansun, Y.X.; Chen, R.; Lin, L.; Lin, Y.; Li, J.G. Mesenchymal stem cell exosomes promote immunosuppression of reg-ulatory T cells in asthma. Exp. Cell Res. 2018, 363, 114-120. [CrossRef] [PubMed]

55. Vigorito, A.C.; Campregher, P.V.; Storer, B.E.; Carpenter, P.A.; Moravec, C.K.; Kiem, H.-P.; Fero, M.L.; Warren, E.H.; Lee, S.J.; Appelbaum, F.R.; et al. Evaluation of NIH consensus criteria for classification of late acute and chronic GVHD. Blood 2009, 114, 702-708. [CrossRef] [PubMed]

56. Weng, J.Y.; Du, X.; Geng, S.X.; Peng, Y.W.; Wang, Z.; Lu, Z.S.; Wu, S.J.; Luo, C.W.; Guo, R.; Ling, W.; et al. Mesenchymal stem cell as salvage treatment for refractory chronic GVHD. Bone Marrow Transplant. 2010, 45, 1732-1740. [CrossRef]

57. Nassar, A.; Tabbara, K.F.; Aljurf, M. Ocular manifestations of graft-versus-host disease. Saudi J. Ophthalmol. 2013, $27,215-222$. [CrossRef] [PubMed]

58. Weng, J.; He, C.; Lai, P.; Luo, C.; Guo, R.; Wu, S.; Geng, S.; Xiangpeng, A.; Liu, X.; Du, X. Mesenchymal Stromal cells treatment attenuates dry eye in patients with chronic graft-versus-host disease. Mol. Ther. 2012, 20, 2347-2354. [CrossRef] [PubMed]

59. Katsarou, A.; Gudbjörnsdottir, S.; Rawshani, A.; Dabelea, D.; Bonifacio, E.; Anderson, B.J.; Jacobsen, M.L.; Schat, D.A.; Lenmark, A. Type 1 diabetes mellitus. Nat. Rev. Dis. Primers 2017, 3, 1-17. [CrossRef]

60. Cooke, D.W.; Plotnick, L. Type 1 Diabetes Mellitus in pediatrics. Pediatr. Rev. 2008, 29, 374-385. [CrossRef]

61. Nojehdehi, S.; Soudi, S.; Hesampour, A.; Rasouli, S.; Soleimani, M.; Hashemi, S.M. Immunomodulatory effects of mesenchymal stem cell-derived exosomes on experimental type-1 autoimmune diabetes. J. Cell. Biochem. 2018, 119, 9433-9443. [CrossRef]

62. Mahdipour, E.; Salmasi, Z.; Sabeti, N. Potential of stem cell-derived exosomes to regenerate $\beta$ islets through Pdx-1 dependent mechanism in a rat model of type 1 diabetes. J. Cell. Physiol. 2019, 234, 20310-20321. [CrossRef] [PubMed]

63. Hajishengallis, G. Periodontitis: From microbial immune subversion to systemic inflammation. Nat. Rev. Immunol. 2015, 15, 30-44. [CrossRef] [PubMed]

64. Xu, X.Y.; Tian, B.M.; Xia, Y.; Xia, Y.L.; Li, X.; Zhou, H.; Tan, Y.Z.; Chen, F.M. Exosomes derived from P2X7 receptor gene-modified cells rescue inflammation-compromised periodontal ligament stem cells from dysfunction. Stem Cells Transl. Med. 2020, 9 , 1414-1430. [CrossRef] [PubMed]

65. Zheng, Y.; Dong, C.; Yang, J.; Jin, Y.; Zheng, W.; Zhou, Q.; Liang, Y.; Bao, L.; Feng, G.; Ji, J.; et al. Exosomal microRNA-155-5p from PDLSCs regulated Th17/Treg balance by targeting sirtuin-1 in chronic periodontitis. J. Cell. Physiol. 2019, 234, 20662-20674. [CrossRef]

66. Chew, J.R.J.; Chuah, S.J.; Teo, K.Y.W.; Zhang, S.; Lai, R.C.; Fu, J.H.; Lim, L.P.; Lim, S.K.; Toh, W.S. Mesenchymal stem cell exosomes enhance periodontal ligament cell functions and promote periodontal regeneration. Acta Biomater. 2019, 89, 252-264. [CrossRef] [PubMed]

67. Duchnowski, P.; Hryniewiecki, T.; Kuśmierczyk, M.; Szymanski, P. Red cell distribution width as a predictor of multiple organ dysfunction syndrome in patients undergoing heart valve surgery. Biol. Open 2018, 7, bio036251. [CrossRef] [PubMed]

68. Haasper, C.; Kalmbach, M.; Dikos, G.D.; Meller, R.; Müller, C.; Krettek, C.; Hildebrand, F.; Frink, M. Prognostic value of procalcitonin (PCT) and/or inter-leukin-6 (IL-6) plasma levels after multiple trauma for the development of multi organ dysfunction syndrome (MODS) or sepsis. Technol. Health Care 2010, 18, 89-100. [CrossRef] [PubMed]

69. Sapan, H.B.; Paturusi, I.; Jusuf, I.; Patellongi, I.; Massi, M.N.; Pusponegoro, A.D.; Arief, S.K.; Labeda, I.; Islam, A.A.; Rendy, L.; et al. Pattern of cytokine (IL-6 and IL-10) level as inflammation and anti-inflammation mediator of multiple organ dysfunction syndrome (MODS) in polytrauma. Int. J. Burn. Trauma 2016, 6, 37-43.

70. Zhang, B.; Wang, M.; Gong, A.; Zhang, X.; Wu, X.; Zhu, Y.; Shi, H.; Wu, L.; Zhu, W.; Qian, H.; et al. HucMSC-exosome mediated-Wnt4 signaling is required for cutaneous wound healing. Stem Cells 2015, 33, 2158-2168. [CrossRef] [PubMed] 
71. Zhang, J.; Guan, J.; Niu, X.; Shangchun, G.; Guo, S.; Li, Q.; Xie, Z.; Zhang, C.; Wang, Y. Exosomes released from human induced pluripotent stem cells-derived MSCs facilitate cutaneous wound healing by promoting collagen synthesis and angiogenesis. J. Transl. Med. 2015, 13,1-14. [CrossRef]

72. Shabbir, A.; Cox, A.; Rodriguez-Menocal, L.; Salgado, M.; Van Badiavas, E. Mesenchymal Stem cell exosomes induce proliferation and migration of normal and chronic wound fibroblasts, and enhance angiogenesis in vitro. Stem Cells Dev. 2015, 24, 1635-1647. [CrossRef]

73. Shi, Q.; Qian, Z.; Liu, D.; Sun, J.; Wang, X.; Liu, H.; Xu, J.; Guo, X. GMSC-Derived Exosomes Combined with a chitosan/silk hydrogel sponge accelerates wound healing in a diabetic rat skin defect model. Front. Physiol. 2017, 8, 904. [CrossRef]

74. Li, B.; Luan, S.; Chen, J.; Zhou, Y.; Wang, T.; Li, Z.; Fu, Y.; Zhai, A.; Bi, C. The MSC-derived exosomal lncRNA H19 promotes Wound healing in diabetic foot ulcers by upregulating PTEN via MicroRNA-152-3p. Mol. Ther. Nucleic Acids 2020, 19, 814-826. [CrossRef]

75. Fine, J.-D. Inherited epidermolysis bullosa. Orphanet J. Rare Dis. 2010, 5, 1-17. [CrossRef]

76. McBride, J.D.; Rodriguez-Menocal, L.; Candanedo, A.; Guzman, W.; Garcia-Contreras, M.; Badiavas, E.V. Dual mechanism of type VII collagen transfer by bone marrow mesenchymal stem cell extracellular vesicles to recessive dystrophic epidermolysis bullosa fibro-blasts. Biochimie 2018, 155, 50-58. [CrossRef] [PubMed]

77. Rashidghamat, E.; Kadiyirire, T.; Ayis, S.; Petrof, G.; Liu, L.; Pullabhatla, V.; Ainali, C.; Guy, A.; Aristodemou, S.; McMillan, J.R.; et al. Phase I/II open-label trial of intravenous allogeneic mesenchymal stromal cell therapy in adults with recessive dystrophic epidermolysis bullosa. J. Am. Acad. Dermatol. 2020, 83, 447-454. [CrossRef] [PubMed]

78. Kuriyama, S.; Hayashi, H.; Jingami, Y.; Kuramoto, N.; Akita, J.; Matsumoto, M. Efficacy of Inverted internal limiting membrane flap technique for the treatment of macular hole in high myopia. Am. J. Ophthalmol. 2013, 156, 125-131.e1. [CrossRef]

79. Zhang, X.; Liu, J.; Yu, B.; Ma, F.; Ren, X.; Li, X. Effects of mesenchymal stem cells and their exosomes on the healing of large and refractory macular holes. Graefe's Arch. Clin. Exp. Ophthalmol. 2018, 256, 2041-2052. [CrossRef]

80. Doeppner, T.R.; Bähr, M.; Giebel, B.; Hermann, D.M. Immunological and non-immunological effects of stem cell-derived extra-cellular vesicles on the ischaemic brain. Ther. Adv. Neurol. Disord. 2018, 11. [CrossRef]

81. Alvarez-Erviti, L.; Seow, Y.; Yin, H.; Betts, C.; Lakhal, S.; Wood, M.J.A. Delivery of siRNA to the mouse brain by systemic injection of targeted exosomes. Nat. Biotechnol. 2011, 29, 341-345. [CrossRef] [PubMed]

82. Xin, H.; Katakowski, M.; Wang, F.; Qian, J.-Y.; Liu, X.S.; Ali, M.M.; Buller, B.; Zhang, Z.G.; Chopp, M. MicroRNA-17-92 Cluster in Exosomes enhance neuroplasticity and functional recovery after stroke in rats. Stroke 2017, 48, 747-753. [CrossRef] [PubMed]

83. Cui, G.H.; Guo, H.D.; Li, H.; Zhai, Y.; Gong, Z.B.; Wu, J.; Liu, J.S.; Dong, Y.R.; Hou, S.X.; Liu, J.R. RVG-modified exosomes derived from mesenchymal stem cells rescue memory deficits by regulating inflammatory responses in a mouse model of Alzheimer's disease. Immun. Ageing 2019, 16, 1-12. [CrossRef] [PubMed]

84. Hanson, L.R.; Frey, W.H. Intranasal delivery bypasses the blood-brain barrier to target therapeutic agents to the central nervous system and treat neurodegenerative disease. BMC Neurosci. 2008, 9, S5. [CrossRef]

85. Long, Q.; Upadhya, D.; Hattiangady, B.; Kim, D.-K.; An, S.Y.; Shuai, B.; Prockop, D.J.; Shetty, A.K. Intranasal MSC-derived A1-exosomes ease inflammation, and prevent abnormal neurogenesis and memory dysfunction after status epilepticus. Proc. Natl. Acad. Sci. USA 2017, 114, E3536-E3545. [CrossRef]

86. Perets, N.; Hertz, S.; London, M.; Offen, D. Intranasal administration of exosomes derived from mesenchymal stem cells amelio-rates autistic-like behaviors of BTBR mice. Mol. Autism 2018, 9, 57. [CrossRef]

87. Roth, G.A.; Huffman, M.D.; Moran, A.E.; Feigin, V.L.; Mensah, G.A.; Naghavi, M.; Murray, C.J. Global and regional patterns in cardiovascular mortality from 1990 to 2013. Circulation 2015, 132, 1667-1678. [CrossRef] [PubMed]

88. Shpilsky, D.; Bambs, C.; Kip, K.; Patel, S.; Aiyerv, A.; Olafiranye, O.; Reis, S.E.; Erqou, S. Association between ideal cardiovascular health and markers of subclinical cardiovascular disease. Clin. Cardiol. 2018, 41, 1593-1599. [CrossRef] [PubMed]

89. Zhou, M.; Wang, H.; Zeng, X.; Yin, P.; Zhu, J.; Chen, W.; Li, X.; Wang, L.; Wang, L.; Liu, Y.; et al. Mortality, morbidity, and risk factors in China and its provinces, 1990-2017: A systematic analysis for the Global burden of disease study. Lancet 2019, 394, 1145-1158. [CrossRef]

90. Freyman, T.; Polin, G.; Osman, H.; Crary, J.; Lu, M.; Cheng, L.; Palasis, M.; Wilensky, R.L. A quantitative, randomized study evaluating three methods of mesenchymal stem cell delivery following myocardial infarction. Eur. Heart J. 2006, 27, 1114-1122. [CrossRef]

91. Timmers, L.; Lim, S.K.; Hoefer, I.E.; Arslan, F.; Lai, R.C.; Van Oorschot, A.A.; Goumans, M.-J.; Strijder, C.; Sze, S.K.; Choo, A.; et al. Human mesenchymal stem cell-conditioned medium improves cardiac function following myocardial infarction. Stem Cell Res. 2011, 6, 206-214. [CrossRef]

92. Shao, L.; Zhang, Y.; Lan, B.; Wang, J.; Zhang, Z.; Zhang, L.; Xiao, P.; Meng, Q.; Geng, Y.J.; Yu, X.Y. MiRNA-sequence indicates that mesenchymal stem cells and ex-osomes have similar mechanism to enhance cardiac repair. BioMed Res. Int. 2017. [CrossRef]

93. Wang, K.; Jiang, Z.; Webster, K.A.; Chen, J.; Hu, H.; Zhou, Y.; Zhao, J.; Wang, L.; Wang, Y.; Zhong, Z.; et al. Enhanced cardioprotection by human endometrium mesenchymal stem cells driven by exosomal MicroRNA-21. Stem Cells Transl. Med. 2016, 6, 209-222. [CrossRef]

94. Peng, Y.; Zhao, J.L.; Peng, Z.Y.; Xu, W.F.; Yu, G.L. Exosomal miR-25-3p from mesenchymal stem cells alleviates myocardial in-farction by targeting pro-apoptotic proteins and EZH2. Cell Death Dis. 2020, 11, 1-15. 
95. Ono, M.; Kosaka, N.; Tominaga, N.; Yoshioka, Y.; Takeshita, F.; Takahashi, R.-U.; Yoshida, M.; Tsuda, H.; Tamura, K.; Ochiya, T. Exosomes from bone marrow mesenchymal stem cells contain a microRNA that promotes dormancy in metastatic breast cancer cells. Sci. Signal. 2014, 7, ra63. [CrossRef] [PubMed]

96. Bliss, S.A.; Sinha, G.; Sandiford, O.A.; Williams, L.M.; Engelberth, D.J.; Guiro, K.; Isenalumhe, L.L.; Greco, S.J.; Ayer, S.; Bryan, M.; et al. Mesenchymal stem cell-derived exosomes stimulate cycling quiescence and early breast cancer dormancy in bone marrow. Cancer Res. 2016, 76, 5832-5844. [CrossRef] [PubMed]

97. Widner, D.B.; Park, S.H.; Eber, M.R.; Shiozawa, Y. Interactions between disseminated tumor cells and bone marrow stromal cells regulate tumor dormancy. Curr. Osteoporos. Rep. 2018, 16, 596-602. [CrossRef] [PubMed]

98. Ji, R.; Zhang, B.; Zhang, X.; Xue, J.; Yuan, X.; Yan, Y.; Wang, M.; Zhu, W.; Qian, H.; Xu, W. Exosomes derived from human mesenchymal stem cells confer drug resistance in gastric cancer. Cell Cycle 2015, 14, 2473-2483. [CrossRef] [PubMed]

99. Lee, J.-K.; Park, S.-R.; Jung, B.-K.; Jeon, Y.-K.; Lee, Y.-S.; Kim, M.-K.; Kim, Y.-G.; Jang, J.-Y.; Kim, C.-W. Exosomes Derived from mesenchymal stem cells suppress angiogenesis by down-regulating vegf expression in breast cancer cells. PLoS ONE 2013, 8, e84256. [CrossRef]

100. Lin, R.; Wang, S.-H.; Zhao, R.C. Exosomes from human adipose-derived mesenchymal stem cells promote migration through Wnt signaling pathway in a breast cancer cell model. Mol. Cell. Biochem. 2013, 383, 13-20. [CrossRef] [PubMed]

101. Gu, H.; Ji, R.; Zhang, X.; Wang, M.; Zhu, W.; Qian, H.; Chen, Y.; Jiang, P.; Xu, W. Exosomes derived from human mesenchymal stem cells promote gastric cancer cell growth and migration via the activation of the Akt pathway. Mol. Med. Rep. 2016, 14, 3452-3458. [CrossRef]

102. Vakhshiteh, F.; Atyabi, F.; Ostad, S.N. Mesenchymal stem cell exosomes: A two-edged sword in cancer therapy. Int. J. Nanomed. 2019, 14, 2847-2859. [CrossRef] [PubMed]

103. Zhou, J.; Tan, X.; Tan, Y.; Li, Q.; Ma, J.; Wang, G. Mesenchymal Stem cell derived exosomes in cancer progression, metastasis and drug delivery: A comprehensive review. J. Cancer 2018, 9, 3129-3137. [CrossRef] [PubMed]

104. Melzer, C.; Rehn, V.; Yang, Y.; Bähre, H.; Von Der Ohe, J.; Hass, R. Taxol-loaded MSC-derived exosomes provide a therapeutic vehicle to target metastatic breast cancer and other carcinoma cells. Cancers 2019, 11, 798. [CrossRef] [PubMed]

105. Kalimuthu, S.; Gangadaran, P.; Rajendran, R.L.; Zhu, L.; Oh, J.M.; Lee, H.W.; Gopal, A.; Baek, S.H.; Jeong, S.Y.; Lee, S.-W.; et al. A New approach for loading anticancer drugs into mesenchymal stem cell-derived exosome mimetics for cancer therapy. Front. Pharmacol. 2018, 9, 1116. [CrossRef]

106. Greco, K.A.; Franzen, C.A.; Foreman, K.E.; Flanigan, R.C.; Kuo, P.C.; Gupta, G. PLK-1 Silencing in bladder cancer by siRNA Delivered with exosomes. Urology 2016, 91, 241-e1. [CrossRef] [PubMed]

107. Kamerkar, S.; LeBleu, V.S.; Sugimoto, H.; Yang, S.; Ruivo, C.F.; Melo, S.A.; Lee, J.J.; Kalluri, R. Exosomes facilitate therapeutic targeting of oncogenic KRAS in pancreatic cancer. Nat. Cell Biol. 2017, 546, 498-503. [CrossRef]

108. Mendt, M.; Kamerkar, S.; Sugimoto, H.; McAndrews, K.M.; Wu, C.C.; Gagea, M.; Yang, S.; Blanko, E.V.R.; Peng, Q.; Ma, X.; et al. Generation and testing of clinical-grade exosomes for pancreatic cancer. JCI Insight 2018, 3. [CrossRef]

109. Cai, Q.; Yang, M.; Liu, D.; Chen, J.; Shu, D.; Xia, J.; Liao, X.; Gu, Y.; Cai, Q.; Yang, Y.; et al. Experimental treatment with favipiravir for COVID-19: An open-label control study. Engineering 2020. [CrossRef]

110. Choy, K.T.; Wong, A.Y.L.; Kaewpreedee, P.; Sia, S.F.; Chen, D.; Hui, K.P.Y.; Chu, D.K.W.; Chan, M.C.W.; Cheung, P.P.H.; Huang, X.; et al. Remdesivir, lopinavir, emetine, and homoharring-tonine inhibit SARS-CoV-2 replication in vitro. Antivir. Res. 2020, 178, 104786. [CrossRef]

111. Grein, J.; Ohmagari, N.; Shin, D.; Diaz, G.; Asperges, E.; Castagna, A.; Feldt, T.; Green, G.; Green, M.L.; Lescure, F.-X.; et al. Compassionate use of Remdesivir for patients with severe Covid-19. Engl. J. Med. 2020, 382, 2327-2336. [CrossRef]

112. Horby, P.; Lim, S.W.; Emberson, J.R.; Mafham, M.; Bell, J.L.; Linsell, L.; Staplin, N.; Brightling, C.; Utstianowski, A.; Elmahi, E.; et al. Dexamethasone in hospitalized patients with Covid-19-Preliminary report. N. Engl. J. Med. 2020. [CrossRef]

113. Yao, X.; Ye, F.; Zhang, M.; Cui, C.; Huang, B.; Niu, P.; Liu, X.; Zhao, L.; Dong, E.; Song, C.; et al. In vitro antiviral activity and projection of optimized dosing design of hydroxychloroquine for the treatment of severe acute respiratory syndrome coronavirus 2 (SARS-CoV-2). Clin. Infect. Dis. 2020, 15, 732-739. [CrossRef]

114. Yin, W.; Mao, C.; Luan, X.; Shen, D.D.; Shen, Q.; Su, H.; Wang, X.; Zhou, F.; Zhao, W.; Gao, M.; et al. Structural basis for inhibition of the RNA-dependent RNA polymerase from SARS-CoV-2 by remdesivir. Science 2020, 368, 1499-1504. [CrossRef] [PubMed]

115. Rothan, H.A.; Byrareddy, S.N. The epidemiology and pathogenesis of coronavirus disease (COVID-19) outbreak. J. Autoimmun. 2020, 109, 102433. [CrossRef] [PubMed]

116. Li, W.; Moore, M.J.; Vasilieva, N.; Sui, J.; Wong, S.K.; Berne, M.A.; Somasundaran, M.; Sullivan, J.L.; Luzuriaga, K.; Greenough, T.C.; et al. Angiotensin-converting enzyme 2 is a functional receptor for the SARS coronavirus. Nature 2003, 426, 450-454. [CrossRef] [PubMed]

117. Xu, Z.; Shi, L.; Wang, Y.; Zhang, J.; Huang, L.; Zhang, C.; Liu, S.; Zhao, P.; Liu, H.; Zhu, L.; et al. Pathological findings of COVID-19 associated with acute respiratory distress syndrome. Lancet Respir. Med. 2020, 8, 420-422. [CrossRef]

118. Li, X.; Geng, M.; Peng, Y.; Meng, L.; Lu, S. Molecular immune pathogenesis and diagnosis of COVID-19. J. Pharm. Anal. 2020, 10, 102-108. [CrossRef] [PubMed]

119. Huang, C.; Wang, Y.; Li, X.; Ren, L.; Zhao, J.; Hu, Y.; Zhang, L.; Fan, G.; Xu, J.; Gu, X.; et al. Clinical features of patients infected with 2019 novel coronavirus in Wuhan, China. Lancet 2020, 395, 497-506. [CrossRef] 
120. Chaubey, S.; Thueson, S.; Ponnalagu, D.; Alam, M.A.; Gheorghe, C.P.; Aghai, Z.; Singh, H.; Bhandari, V. Early gestational mesenchymal stem cell secretome attenuates experimental bronchopulmonary dysplasia in part via exosome-associated factor TSG-6. Stem Cell Res Ther. 2018, 9, 1-26. [CrossRef]

121. Abraham, A.; Krasnodembskaya, A. Mesenchymal stem cell-derived extracellular vesicles for the treatment of acute respiratory distress syndrome. Stem Cells Transl. Med. 2020, 9, 28-38. [CrossRef]

122. Chen, J.; Hu, C.; Chen, L.; Tang, L.; Zhu, Y.; Xu, X.; Chen, L.; Gao, H.; Lu, X.; Yu, L.; et al. Clinical study of mesenchymal stem cell treating acute respiratory distress syndrome induced by epidemic Influenza A (H7N9) infection, a hint for COVID-19 treatment. Engineering 2020, 10, 1153-1161. [CrossRef]

123. Khatri, M.; Richardson, L.A.; Meulia, T. Mesenchymal stem cell-derived extracellular vesicles attenuate influenza virus-induced acute lung injury in a pig model. Stem Cell Res. Ther. 2018, 9, 1-13. [CrossRef]

124. Li, Y.; Xu, J.; Shi, W.; Chen, C.; Shao, Y.; Zhu, L.; Lu, W.; Han, X. Mesenchymal stromal cell treatment prevents H9N2 avian influenza virus-induced acute lung injury in mice. Stem Cell Res. Ther. 2016, 7, 59. [CrossRef]

125. Tsuchiya, A.; Takeuchi, S.; Iwasawa, T.; Kumagai, M.; Sato, T.; Motegi, S.; Ishii, Y.; Koseki, Y.; Tomiyoshi, K.; Natsui, K.; et al. Therapeutic potential of mesenchymal stem cells and their exosomes in severe novel coronavirus disease 2019 (COVID-19) cases. Inflamm. Regen. 2020, 40,1-6. [CrossRef]

126. Taghavi-Farahabadi, M.; Mahmoudi, M.; Soudi, S.; Hashemi, S.M. Hypothesis for the management and treatment of the COVID19-induced acute respiratory distress syndrome and lung injury using mesenchymal stem cell-derived exosomes. Med. Hypotheses 2020, 144, 109865. [CrossRef]

127. Sengupta, V.; Sengupta, S.; Lazo, A.; Woods, P.; Nolan, A.; Bremer, N. Exosomes derived from bone marrow Mesenchymal stem cells as treatment for Severe COVID-19. Stem Cells Dev. 2020, 29, 747-754. [CrossRef]

128. Muraca, M.; Pessina, A.; Pozzobon, M.; Dominici, M.; Galderisi, U.; Lazzari, L.; Parolini, O.; Lucarelli, E.; Perilongo, G.; Baraldi, E. Mesenchymal stromal cells and their secreted extracellular vesicles as therapeutic tools for COVID-19 pneumonia? J. Control. Release 2020, 325, 135-140. [CrossRef]

129. Panigada, M.; Bottino, N.; Tagliabue, P.; Grasselli, G.; Novembrino, C.; Chantarangkul, V.; Pesenti, A.; Peyvandi, F.; Tripodi, A. Hypercoagulability of COVID-19 patients in intensive care unit: A report of thromboelastography findings and other parameters of hemostasis. J. Thromb. Haemost. 2020, 18, 1738-1742. [CrossRef]

130. Levi, M.; Thachil, J.; Iba, T.; Levy, J.H. Coagulation abnormalities and thrombosis in patients with COVID-19. Lancet Haematol. 2020, 7, e438-e440. [CrossRef]

131. Mao, G.; Zhang, Z.; Hu, S.; Zhang, Z.; Chang, Z.; Huang, Z.; Liao, W.; Kang, Y. Exosomes derived from miR-92a-3p-overexpressing human mesenchymal stem cells enhance chondrogenesis and suppress cartilage degradation via targeting WNT5A. Stem Cell Res. Ther. 2018, 9, 1-13. [CrossRef] [PubMed]

132. Chen, S.; Tang, Y.; Liu, Y.; Zhang, P.; Lv, L.; Zhang, X.; Jia, L.; Zhou, Y. Exosomes derived from miR-375-overexpressing human adipose mes-enchymal stem cells promote bone regeneration. Cell Prolif. 2019, 52, e12669. [CrossRef] [PubMed]

133. Che, Y.; Shi, X.; Shi, Y.; Jiang, X.; Ai, Q.; Shi, Y.; Gong, F.; Jiang, W. Exosomes Derived from miR-143-Overexpressing MSCs Inhibit cell migration and invasion in human prostate cancer by downregulating TFF3. Mol. Ther. Nucleic Acids 2019, 18, 232-244. [CrossRef] [PubMed]

134. Kang, K.; Ma, R.; Cai, W.; Huang, W.; Paul, C.; Liang, J.; Wang, Y.; Zhao, T.; Kim, H.W.; Xu, M.; et al. Exosomes secreted from CXCR4 Overexpressing mesenchymal stem cells promote cardioprotection via Akt signaling pathway following myocardial infarction. Stem Cells Int. 2015, 2015, 1-14. [CrossRef] [PubMed]

135. Yu, B.; Kim, H.W.; Gong, M.; Wang, J.; Millard, R.W.; Wang, Y.; Ashraf, M.; Xu, M. Exosomes secreted from GATA-4 overexpressing mesenchymal stem cells serve as a reservoir of anti-apoptotic microRNAs for cardioprotection. Int. J. Cardiol. 2015, 182, 349-360 [CrossRef]

136. Donoso-Quezada, J.; Ayala-Mar, S.; González-Valdez, J. State-of-the-art exosome loading and functionalization techniques for enhanced therapeutics: A review. Crit. Rev. Biotechnol. 2020, 40, 804-820. [CrossRef]

137. Sun, D.; Zhuang, X.; Xiang, X.; Liu, Y.; Zhang, S.; Liu, C.; Barnes, S.; Grizzle, W.; Miller, D.; Zhang, H.-G. A Novel nanoparticle drug delivery system: The Anti-inflammatory activity of curcumin is enhanced when encapsulated in exosomes. Mol. Ther. 2010, 18, 1606-1614. [CrossRef]

138. Zhuang, X.; Xiang, X.; Grizzle, W.; Sun, D.; Zhang, S.; Axtell, R.C.; Ju, S.; Mu, J.; Zhang, L.; Steinman, L.; et al. Treatment of Brain inflammatory diseases by delivering exosome encapsulated anti-inflammatory drugs from the nasal region to the brain. Mol. Ther. 2011, 19, 1769-1779. [CrossRef]

139. Huang, L.; Gu, N.; Zhang, M.; Wang, D.-B. Light-Inducible exosome-based vehicle for endogenous rna loading and delivery to Leukemia Cells. Adv. Funct. Mater. 2019, 29. [CrossRef]

140. Yang, Z.; Xie, J.; Zhu, J.; Kang, C.; Chiang, C.; Wang, X.; Wang, X.; Kuang, T.; Chen, F.; Chen, Z.; et al. Functional exosome-mimic for delivery of siRNA to cancer: In vitro and in vivo evaluation. J. Control. Release 2016, 243, 160-171. [CrossRef]

141. Zhang, K.; Zhao, X.; Chen, X.; Wei, Y.; Du, W.; Wang, Y.; Liu, L.; Zhao, W.; Han, Z.; Kong, D.; et al. Enhanced therapeutic effects of mesenchymal stem cell-derived ex-osomes with an injectable hydrogel for hindlimb ischemia treatment. ACS Appl. Mater. Interfaces 2018, 10, 30081-30091. [CrossRef] 
142. Yang, J.; Chen, Z.; Pan, D.; Li, H.; Shen, J. Umbilical Cord-derived mesenchymal stem cell-derived exosomes combined pluronic F127 Hydrogel promote chronic diabetic wound healing and complete skin regeneration. Int. J. Nanomed. 2020, 15, 5911-5926. [CrossRef] [PubMed]

143. Zhang, J.; Liu, X.; Li, H.; Chen, C.; Chunyuan, C.; Niu, X.; Li, Q.; Zhao, B.; Xie, Z.; Wang, Y. Exosomes/tricalcium phosphate combination scaffolds can enhance bone regeneration by activating the PI3K/Akt signaling pathway. Stem Cell Res. Ther. 2016, 7, 1-14. [CrossRef] [PubMed]

144. Xin, L.; Lin, X.; Zhou, F.; Li, C.; Wang, X.; Yu, H.; Pan, Y.; Fei, H.; Ma, L.; Zhang, S. A scaffold laden with mesenchymal stem cellderived exosomes for promoting endometrium regeneration and fertility restoration through macrophage immunomodulation. Acta Biomater. 2020, 113, 252-266. [CrossRef]

145. Chen, P.; Zheng, L.; Wang, Y.; Tao, M.; Xie, Z.; Xia, C.; Gu, C.; Chen, J.; Qiu, P.; Mei, S.; et al. Desktop-stereolithography 3D printing of a radially oriented extracellular matrix/mesenchymal stem cell exosome bioink for osteochondral defect regeneration. Theranostics 2019, 9, 2439-2459. [CrossRef] [PubMed]

146. Ti, D.; Hao, H.; Tong, C.; Liu, J.; Dong, L.; Zheng, J.; Zhao, Y.; Liu, H.; Fu, X.; Wan, W. LPS-preconditioned mesenchymal stromal cells modify macrophage po-larization for resolution of chronic inflammation via exosome-shuttled let-7b. J. Transl. Med. 2015, 13, 308. [CrossRef]

147. Tamura, R.; Uemoto, S.; Tabata, Y. Augmented liver targeting of exosomes by surface modification with cationized pullulan. Acta Biomater. 2017, 57, 274-284. [CrossRef]

148. Grange, C.; Tapparo, M.; Bruno, S.; Chatterjee, D.; Quesenberry, P.J.; Tetta, C.; Camussi, G. Biodistribution of mesenchymal stem cell-derived extracellular vesicles in a model of acute kidney injury monitored by optical imaging. Int. J. Mol. Med. 2014, 33, 1055-1063. [CrossRef]

149. Wiklander, O.P.B.; Nordin, J.Z.; O’Loughlin, A.; Gustafsson, Y.; Corso, G.; Mäger, I.; Vader, P.; Lee, Y.; Sork, H.; Seow, Y.; et al. Extracellular vesicle in vivo biodistribution is determined by cell source, route of administration and targeting. J. Extracell. Vesicles 2015, 4, 26316. [CrossRef] 